\title{
International Business Students' Understanding, Perception, and Commitment to Corporate Social Responsibility: A Study Based upon Gender, Generational Affiliation, and Culture
}

\author{
Belal A. Kaifi ${ }^{1}$, Nile M. Khanfar ${ }^{2}$, Ahmad O. Noor $^{2} \&$ Laura Poluka $^{1}$ \\ ${ }^{1}$ College of Business Administration, Trident University International, 5757 Plaza Drive, Suite.100, Cypress, CA \\ 90630, USA \\ ${ }^{2}$ College of Pharmacy, Palm Beach, Nova Southeastern University, 11501 N. Military Trail, Palm Beach Gardens, FL \\ 33410 , USA
}

Correspondence: Nile M. Khanfar, College of Pharmacy, Palm Beach, Nova Southeastern University, 11501 N. Military Trail, Palm Beach Gardens, FL 33410, USA. Tel: 1-561-805-2242, Fax: 1-561-805-2170, E-mail: khanfar@nova.edu

Received: July 10, 2014

Accepted: August 15, $2014 \quad$ Online Published: August 25, 2014

doi: 10.5430/bmr.v3n3p34

URL: http://dx.doi.org/10.5430/bmr.v3n3p34

\begin{abstract}
Much discourse has taken place over the topic of corporate social responsibility since the late $20^{\text {th }}$ century. As such, universities are preparing students for embracing and dealing with corporate social responsibility dilemmas by incorporating corporate social responsibility topics in the curriculum. This quantitative empirical research surveyed undergraduate students $(\mathrm{N}=180)$ majoring in International Business to learn more about their commitment to corporate social responsibility. A total of 80 male and 100 female students were surveyed. The results of this research suggest that female students have a higher commitment to corporate social responsibility, students born in a high-context culture have a higher commitment to corporate social responsibility, and millennials have a higher commitment to corporate social responsibility. Implications and recommendations are offered for practitioners and educators.
\end{abstract}

Keywords: Corporate social responsibility, Gender, Culture, Millennials (Generation Y), Generation X

\section{Introduction}

Initially, Bowen (1953) wrote an influential book titled Social Responsibilities of the Businessman, which delineated the importance of corporate social responsibility (CSR). Events relative to Corporate Social Responsibility (CSR) have brought much public attention due to its ambiguous nature over the years. Numerous CSR studies have been conducted in the areas of gender, age and religion/ culture. However, there are contradictory results across multiple studies examined. In reality, government regulation and shareholders motivate CSR in order to a gain competitive advantage over their adversaries (Choudhary \& Singh, 2012). Corporations have an ethical commitment to their community, gender diversity, and tolerance among differing cultures (Kaifi, 2013). Only until recently has the world viewed CSR as a tool to expand their companies and corporate not philanthropy (Choudhary \& Singh, 2012). Although many companies have mission statements emphasizing ethical commitment, many do this for superficial public relations and overall perceived image. The main research questions for this study are: Do students studying International Business have a commitment to corporate social responsibility once they graduate and enter the workforce? Does gender, generational affiliation, and/or culture play a role? Who should HR managers hire?

\section{Literature Review}

\subsection{Corporate Social Responsibility}

There is no universally accepted definition of Corporate Social Responsibility (CSR), however, the definition has evolved over the years and many researchers have attempted to provide a generally accepted definition. Bowen (1953) set forth initial definition of CSR as: "What responsibilities to society may businessmen reasonably be expected to assume?" CSR refers to the obligations of businessmen to pursue those policies, to make those decisions, or to follow those lines of action, which are desirable in terms of the objectives, and values of our society. Interest in politics, in the welfare of the community, in educations, in the "happiness" of its employers, and, in fact, in the 
whole social world about it. Therefore, businesses must act justly as a proper citizen should.

Carroll (1979) referred to CSR as, "The social responsibility of business encompasses the economic, legal, ethical and discretionary expectations that society has of organizations at a given point in time." McWilliams and Siegel (2001) viewed CSR as "situations where the firm goes beyond compliance and engages in actions that appear to further some social good, beyond the interests of the firm and that which is required by law." Kotler and Lee (2005) defined it, as "it is a commitment to improve community well-being through discretionary business practices and contributions of corporate resources."

Finally, Hopkins (2007) proposed a definition he believed that can be characterized as robust enough to frame the meaning of CSR. He defines CSR as follows:

CSR is concerned with treating the stakeholders of the firm ethically or in a responsible manner. 'Ethically or responsible' means treating stakeholders in a manner deemed acceptable in civilized societies. Social includes economic and environmental responsibility. Stakeholders exist both within a firm and outside. The wider aim of social responsibility is to create higher and higher standards of living, while preserving the profitability of the corporation, for people both within and outside the corporation (Hopkins, 2007, p. 15).

\subsection{High-Context and Low-Context Cultural Framework}

Hall (1976) developed the concept of high versus low context cultures in an effort to understand different cultural orientations. He and many other researchers have identified the main dimensions and characteristics that help to clarify and distinguish between high-context and low-context cultures. This concept helps to understand how people in a culture relate to one another and make it possible to order the cultures of the world on a scale from high to low context.

Hall (1976) describes high-context cultures as one in which people are highly involved with each other. A low-context culture is one in which people are highly individualized, somewhat alienated, and fragmented, and there is relatively little involvement with other. High-context cultures rely primarily on non-verbal communication such as body posture, detailed rituals, status, values, and associations (Keegan, 1989) (Nahavandi, 2006) and may draw conclusions from informal interaction (Simintiras \& Thomas, 1998). Personal and organizational integrity is valued deeply and person's word is his or her bond. Business in high context cultures depend more on connections and relationships (Hall, 1983). Gulbro and Herbig (1996) suggest that high-context culture's negotiations are less programmatic and less rigid, particularly in time management, contract signing, and closing deals. In high-context culture responsibility and accountability are taken by the highest levels of management (Hall, 1983). Asian, Arab, Mediterranean, and South American peoples who have extensive information networks among family, friends, colleagues, and clients, and who are involved in close personal relationships, are high-context cultures (Hall, 1976) (Hall, 1987) (Tong, 1992) (Parnell \& Kedia, 1996).

On the other hand, low-context cultures rely on explicit verbal and written communication (Hall, 1983) (Hostede, 1991). In low-context cultures the bonds that tie people together are somewhat fragile, so that people move away if things are not going well (Hall, 1976). They typically stress legalistic approach to business transactions and honor only written word. The responsibility for organizational errors and failures is pushed to the lower levels of the hierarchy (Hall, 1983). Low-context cultures include the U.S., Britain, Canada, Germany, Swiss, Scandinavians, and other northern Europeans (Hall, 1976) (Hall, 1987). Within each culture, of course, there are specific individual differences, but it is helpful to know whether or not the culture of a particular country falls on the high or low side of the scale.

\subsection{Gender Differences in CSR}

Through research of peer reviewed articles relating to differences gender in respect to CSR the following was found. There is a current discrepancy of those in working for corporations that practice CSR. For example, corporations see females as assets to CSR progression but they are currently being under-utilized (Nath, Holder-Webb \& Cohen, 2013). Our research has led us to believe that the increasing demand CSR has not been met.

Research has suggested that women possess the traits necessary to succeed in social roles, namely that they are helpful, communal, and nurturing (Eagly, 2009, 2013). Some feel that female traits such empathy and more thoughtful economic decision make females great assets for CSR positions (Boulouta, 2013). For example research has shown that females are more likely to seek CSR information in regards to financial decisions (Nath et al., 2013). In a large study conducted on about 16,429 individuals in United States, they found after controlling for salary, position level, and age that women donated more to workplace charity than do men (Leslie, Snyder \& Glomb, 2013). 
Another research study looked at the perceptions of CSR among business students showed that women exhibit greater sensitivity to CSR than men.(Fitzpatrick, 2013) Companies with greater board gender diversity showed a positive relationship in regards to their overall performance and were less likely to have negative social business practices (Boulouta, 2013). Moreover, (Leslie et al., 2013) found that increased representation of women has positive consequences for workplace charity at both the individual and work unit levels. Such research is encouraging for females in the workforce and those seeking CSR positions. What is discouraging is that females are unrepresented on corporations board positions world-wide (Boulouta, 2013).

\subsection{Generational Affiliation Differences in CSR}

Research into differences among different generations has been shown in many studies. The current generation has been very critical of companies not taking responsibility for their detrimental actions. The example of the 2010 British Petroleum's oil spill in the Gulf of Mexico has shown how the younger generation has a demand for stricter accountability for companies that cause such catastrophes. Fear that the current generation may have to live with the consequences of such irresponsibly seems to fuel passion for better CSR. Irresponsibly to the environment has caused economic hardship to those living in the Gulf region and it is unknown how much this will carry over to the future generations(Lange \& Washburn, 2012). Younger generations also have shown a greater demand for receiving CSR information and want to have a greater request for provisions (Nath et al., 2013). Particularly in the United States of America where current generation has shown more favorable views for corporations located in the USA than aboard (Kim \& Choi, 2013).

There is a belief that younger generations believe that corporations should practice morally and within their CSR driven mission statements. Research showed that youth have a perception that they have the rightful power to influence companies that is acting in a negligent manner (Kim \& Choi, 2013).

Studies comparing differences and perception toward CSR among various generations are scarce. However, previous research have identified differences in work and career values (Cennamo \& Gardner, 2008) and personality and behaviors (Twenge, Campbell, Hoffman \& Lance, 2010) between different generations.

A study of 238 undergraduate students in Australia looked at millennial students' attitudes towards organizational social responsibility values. The study used hypothetical job choice scenarios, they found that about $54 \%$ of the sample agreed with the proposition that CSR is an important factor in job choice. However, when the hypothetical trade-off posited between higher work rewards and lower CSR, about $58 \%$ of the sample reported that they would consider applying to an organization that offered outstanding rewards but engaged little in CSR and about $18 \%$ maintained their CSR value stance (Leveson \& Joiner, 2014). These findings were consistent with pervious research on millennials suggesting their responsiveness to economic rewards more than other generations (Chen \& Choi, 2008) (Ng, Schweitzer \& Lyons, 2010) (Twenge et al., 2010).

Another study looked at the relationship between person's degree of religiousness and CSR orientation between 411 business managers and professionals (representing baby boomer generation) and 506 undergraduate students (representing $\mathrm{X}$ and $\mathrm{Y}$ generations). The study found that religiousness did influence students' orientation toward CSR of business. However, it did not have any significant impact upon the managers' attitudes. Moreover, when the "low religiousness" students and managers were compared and the "high religiousness" students and managers were compared each pair showed differences in CSR components, which also highlight some generational differences (Ibrahim, Howard \& Angelidis, 2007).

\subsection{Religious/Cultural Differences in CSR}

In a large cross-country sample of over 17,000 individuals drawn from 20 countries to explore the relationship between religious denomination and individual attitudes to CSR, researchers found that religion may play a significant role in shaping individual perceptions of CSR and that there is considerable variation in attitudes to aspects of CSR across religions (Brammer, Williams \& Zinkin, 2007). However, in a study conducted by (Ibrahim et al., 2007) on 411 managers and 506 undergraduate students in the USA, they found that religiousness did influence students' CSR orientation toward the economic, ethical, and philanthropic responsibilities of business, but It did not have any significant impact upon the managers' attitudes.

Research comparing the USA and South Korea showed that overall USA citizens had a more favorable view of companies practicing what they perceived as positive CSR (Kim \& Choi, 2013). In another study comparing the USA, China, and India to assess perceptive differences in corporate social responsibility among business students, "the study found that American and Indian respondents attached more importance to the noneconomic aspects of CSR than Chinese respondents. Chinese students were more accepting of making facilitating payments to get things 
moving. Indian respondents placed more emphasis on philanthropy while the US group emphasized legal obligations of CSR" (Wong, Long \& Elankumaran, 2010). These findings spark interest since all of these countries have different cultural and social structure, histories, and economies, which could influence perceptions of the role of CSR for businesses.

As stated before oil spills can have disastrous consequences to ecosystems and local economies. Current data shows that oil companies operating in the different regions of world treat CSR differently. For example Shell has been reported to having a large portion of their oil spills within Africa compared to North America, South America, Asia, Europe, and the Middle East (Frynas, 2012). Suggesting differences in social structure and religious beliefs may affect the demand for accountable CSR. From the same study oil companies adhering to OPEC reporting of oil spills varied among counties. Those that did not report oil spill were located in either South America, the Middle East, Russia, and Asia most notably China (Frynas, 2012). Suggesting differing cultural or religious beliefs may be involved in the demand for accountability among these companies.

\section{Research Design}

A survey was distributed to 200 undergraduate students majoring in International Business in California to learn about their perception, understanding, and commitment to corporate social responsibility. The undergraduate students were enrolled in four different sections of the same course with the same instructor and the survey was a part of the final exam. Of the 200 surveys that were completed, 20 were not completed correctly. As a result, those 20 surveys were not used. As such, 180 surveys were successfully completed by 80 males and 100 females. This represents a $90 \%$ response rate. This small population sample can be used as a pilot study because of the convenience sampling method, which cannot be generalized to all managers and leaders in the workforce. The specific hypotheses for this study are as follows:

Null Hypothesis 1: Both male and female students will have the same scores as to corporate social responsibility.

Null Hypothesis 2: Students born in a low-context culture and in a high-context culture will have the same scores as to corporate social responsibility.

Null Hypothesis 3: Both Generation Y and Generation X students will have the same scores as to corporate social responsibility.

For the purpose of this study, corporate social responsibility is defined as a process with the aim to embrace responsibility for the company's actions and encourage a positive impact through its activities on the environment, consumers, employees, communities, stakeholders and all other members of the public sphere who may also be considered stakeholders. To the knowledge of the authors, there are no other studies similar to this one. Below is an example of the survey directions, four of the twenty survey questions, and the 5-point likert-type scale, that was used for the 20-question corporate social responsibility survey developed by the authors. The authors created this survey based upon the learning outcomes of the upper-division International Business course that the students were enrolled in at the time. Prior to starting this course, students must have completed the following prerequisite courses: Management, HR Management, and Business Communication. A score of 100 is the highest score one can receive and a score of 20 is the lowest score one can receive.

- Directions: The following statements will help you assess your commitment and understanding of corporate social responsibility.

\begin{tabular}{|l|l|c|c|c|c|c|}
\hline Q1 & $\begin{array}{l}\text { If I was the CEO of an organization, corporate social } \\
\text { responsibility would be my organization's top priority. }\end{array}$ & 1 & 2 & 3 & 4 & 5 \\
\hline Q2 & $\begin{array}{l}\text { If I was the CEO of an organization, I would include } \\
\text { corporate social responsibility in the mission statement of } \\
\text { the organization. }\end{array}$ & 1 & 2 & 3 & 4 & 5 \\
\hline Q3 & $\begin{array}{l}\text { If I was the CEO of an organization, I would hold } \\
\text { monthly trainings on corporate social responsibility. }\end{array}$ & 1 & 2 & 3 & 4 & 5 \\
\hline Q4 & $\begin{array}{l}\text { If I was the CEO of an organization, I would include and } \\
\text { evaluate social corporate responsibility in the } \\
\text { performance review process of all employees. }\end{array}$ & 1 & 2 & 3 & 4 & 5 \\
\hline
\end{tabular}

Please use the following scale:

1. To almost no extent 
2. To a slight extent

3. To a moderate extent

4. To a great extent

5. To a very great extent

Furthermore, demographic questions were asked from each participant regarding: gender, place of birth, cultural affiliation, generational affiliation, work experience, and leadership experience. These questions allowed the researchers to learn more about each student's background. Table 1 summarizes the demographic questions:

Table 1. Participant Demographics

\begin{tabular}{ccccccc}
\hline & Participants & $\begin{array}{c}\text { Generation Y } \\
\text { (Millennials) }\end{array}$ & Generation X & $\begin{array}{c}\text { High-Context } \\
\text { Culture }\end{array}$ & $\begin{array}{l}\text { Low } \\
\text { Context } \\
\text { Culture }\end{array}$ \\
\hline $\begin{array}{c}\text { Males } \\
\text { Females }\end{array}$ & 80 & 70 & 10 & 30 & 50 \\
N = & 100 & 60 & 180 & & 10 & 90 \\
\hline
\end{tabular}

For the purpose of this study, it is imperative to define certain terms/ concepts. A millennial is an individual born after 1980. An individual born in between 1965 and 1980 is affiliated with Generation X. An individual born in between 1946-1964 is considered a baby boomer. Some examples of countries with high-context cultures include: Japan, Afghanistan, and Brazil. Some examples of countries with low-context cultures include: USA, England, and Germany.

\section{Study Results}

For each hypothesis an independent paired sample t-test was used to analyze the data. A total of 80 males and 100 females were surveyed $(\mathrm{N}=180)$. The first hypothesis states that both male and female students will have the same scores as to corporate social responsibility. The results of this hypothesis are as follows:

$(\mathrm{t}=-7.228, \mathrm{p}=0.001)$. As shown in Table 2, males have a significantly higher mean as to commitment to corporate social responsibility than their female counterparts. Thus, the null hypothesis is rejected.

Table 2. Results: Gender

\begin{tabular}{ccc}
\hline Gender & Mean & Standard Deviation \\
\hline Male & 73.2 & 13.37 \\
Female & 86.42 & 8.51 \\
\hline
\end{tabular}

Note: paired samples statistics: $\mathrm{t}=-7.228 ; \mathrm{p}=0.001$

The second hypothesis states that students born in high-context cultures and born in low-context cultures will have the same scores as to corporate social responsibility. The results of this hypothesis are as follows: $(t=7.566, p=0.001)$. As shown in Table 3, those born in high-context cultures have a significantly higher mean as to commitment to corporate social responsibility compared to those born in low-context cultures. Thus, the null hypothesis is rejected.

Table 3. Results: High-Context Culture and Low-Context Culture

\begin{tabular}{lcc}
\multicolumn{1}{c}{ Culture } & Mean & Standard Deviation \\
\hline High-Context Culture & 85.82 & 11.16 \\
Low-Context Culture & 70.25 & 11.56 \\
\hline
\end{tabular}

Note: paired samples statistics: $\mathrm{t}=7.566 ; \mathrm{p}=0.001$

The third hypothesis states that both Generation $\mathrm{Y}$ and Generation X students will have the same scores as to corporate social responsibility. The results of this hypothesis are as follows: $(\mathrm{t}=3.006, \mathrm{p}=0.001)$. As shown in Table 4, Generation Y students have significantly higher mean as to commitment to corporate social responsibility than Generation X students. Thus, the null hypothesis is rejected.

Table 4. Results: Generational Affiliation

\begin{tabular}{ccc}
\hline Generation & Mean & Standard Deviation \\
\hline Generation Y & 78.73 & 14.98 \\
Generation X & 70.96 & 16.87 \\
\hline
\end{tabular}

Note: paired samples statistics: $\mathrm{t}=3.006 ; \mathrm{p}=0.001$ 


\section{Discussion and Managerial Implications}

Consumers want to be able to trust and do business with organizations that have a culture promoting promise and fulfilling obligations. Such characteristics lead us to obligations that focus on honesty and integrity. We see how goodwill and non-opportunistic motives help to create an atmosphere that is simplistic and non-judgmental (Tian, Wang \& Yang, 2011). Women are found to outnumber men in several industries including finance, event planning and education (Orlando, 2012). As a matter of fact, we are seeing more females participating in business fields that were once deemed male dominated. Such professions include engineering and consultancy services.

As there is a shift in women who hold positions that were once male dominated, is the reasoning because of CSR and a commitment to a nurturing environment? With such changes in business and industry, the area of socialization is being ignored as the reason why there are differences in gender expectations and differentiation. The leadership skills that women possess as oppose to men are evident in their management of power, emotional fortitude and conflict resolution. Resulting in such perceptions, has initiated the capability of specific leadership roles and responsibilities (Orlando, 2012).

The personal perception and categorization of members of the different sexes has caused tension and a bias attitude. Environmental learning is one way in which others need to come to terms with such differences and gender variances. As a society we have personal biases that need to be examined to overcome the silo effect and move forward allowing women to integrate more effectively within the workplace (Orlando, 2012).

As the social roles of women are changing and empowerment is a critical component of thought process within organizations, embracing the traditional perception of women's roles within business has changed. Women may still experience a balancing act as there is still a stigma with acceptable behaviors. Until both men and women embrace "the authentic female way of thinking in relevant decision-making processes, the difficulties of balancing feminine and masculine principles will remain" (Debeljak, Krkac \& Ivana, 2011, P.10). The balancing act will cause challenges that impact the achievement of CSR.

Women need to identify with their true potential and focus on believing that they can achieve success without adopting to typical male behaviors. In two studies conducted by Schein in the 1970's showed that there was a perception that both male and female managers needed to possess traits that were associated with men (Debeljak et al., 2011). While we have grown from the 70 's mentality, women are still being treated differently within the workforce. As leaders we need cease judging and try to change individual mindset. Accepting and understanding the different abilities and skills should be complementary and act as a cooperative to create a strategic organization (Gerlach, 2009).

Upon examination of low-context cultures, the results suggest that there is a commitment to explanation and accommodation. Shifts within business today have expanded the opportunities for employees to perform their work requirements. Flexibility in working from home, varied shift schedules and amenities within the work place have changed the way we operate as a society. We are now trying to meet the needs of all employees by providing such flexibility. Helping to create a positive work environment, not only promotes the employee, but the dynamics within the organization as well. Aligning with the needs of all employees can assist in increasing productivity and creation of a culturally acceptable workplace.

Women are often more likely to be trusted within the work place as they show a greater concern for individual needs and expectations. Women are nurturing, caring and sensitive. The alignment of such behaviors also is what is aligned with the transformational way of thinking. If such behaviors are coupled with practices and expectations of CSR the decision making process can be utilized as a reasonable approach enhancing socially responsible behaviors (Debeljak et al., 2011).

In today's society those who are classified as the Gen Y generation have a higher commitment to CSR. Just sit back and think about what has been communicated within the news in recent years. One scandal after another: Enron, World Com, Tyco, AIG, and Bernie Madoff to name just a few. These acts of unethical behavior tarnished organizations and made us as a society think about future implications. Collegiate programs began to add courses that included ethics and social responsibility to heighten awareness of such behaviors communicating what should be done to prevent unethical actions. There is an increasingly significant challenge requiring transfer of knowledge to create the competencies within organizations (Nicolopoulou, 2011).

As managers are required to fill open position requisitions is it only more fitting that those who are hired embrace the expected behaviors? As CSR behaviors are embedded within the minds of the Gen Y population will the future dictate a reduction in unacceptable behaviors? The practical application of CSR and sustainability are components 
promoting accountability and are necessary. These components have an impact on society and can be utilized as corporate governance practices. The appropriate practices need to be in place in order to be meaningful (Nicolopoulou, 2011).

The transfer of knowledge focusing on CSR practices should take place through the revisiting of knowledge and wisdom. Such personal knowledge is an adaptation of choices that are made within the work place. In twenty-first century workplaces one of the additional components that can be utilized to transfer sustainability practices includes practices of talent management (Nicolopoulou, 2011). Identification of such talents can be attained through coaching practices.

Coaching can create a competitive advantage by assisting in sharing of knowledge. Management can take the time to communicate expectations helping the employees to solidify the specific techniques (Nonaka \& Nishiguchi, 2001). It is essential to learn and accumulate new knowledge. Such assistance leads to further dialogue, communication, and assessment of resources that help to promote decision making within the business environment (Baldoni, 2010).

Coaching unlocks the true potential of an employee and creates an awareness, which increases the need to master individual knowledge. Performance and practice are ways employees can gain knowledge and transfer their learning within the workplace (Olivero, Bane \& Kopelman, 1997). Cassidy \& Medsker (2009) indicated coaching is a way to broaden and improve performance and is a motivational technique that helps individuals to reach higher levels of productivity.

\section{Limitations}

There are several limitations to this study. First, a larger sample size may have yielded different results. Next, all of the students sampled in this study are majoring in International Business and a more diverse pool of students (i.e., different majors such as Biology or Engineering) may have yielded unique results. Consequently, additional information regarding work experience may have yielded interesting results. Future researchers should consider the above mentioned limitations when considering a similar study. One more limitation is the survey instrument that was used. This was a customized self-developed instrument which was not taken from an already existing instrument. As such, there is no concurrent validity data presented about the validity of the instrument as well as the reliability. In addition, future researchers should consider investigating the possible link between an individual's religion and their commitment to corporate social responsibility. As such, a qualitative research study may yield useful results that can provide useful theory explaining why individuals have specific views toward social corporate responsibility and what influences those scores. Moreover, future researchers may want to survey managers to derive a more valid conclusion.

\section{Conclusion}

With employees and organizations embracing the notion of corporate social responsibility, it becomes imperative to convey the importance of committing to corporate social responsibility to students as early as possible. Undergraduate curriculum should be modified so every student in all academic departments has knowledge of corporate social responsibility. "Awareness of the impact of business on society and environment has grown along with the growing socio-regulatory pressures" (Sandhu \& Kapoor, 2010, p.47). More specifically, students should know the four main theories of corporate social responsibility by the time they graduate. "Most of current CSR theories are focused on four main aspects: (1) meeting objectives that produce long-term profits, (2) using business power in a responsible way, (3) integrating social demands and (4) contributing to a good society by doing what is ethically correct" (Garriga \& Melé, 2004, p. 65).

Students should consider formulating and implementing a worldwide corporate social responsibility policy that will benefit all. "Although a global economy might conjure a desire for a worldwide CSR policy, a retreat to universalism appears in vain. A disembedding of local relationships and the emergence of new global alignments, actors, and discourses of responsibility apart from particular location is as problematic as suggesting cultural relativism as the solution for creating a global workplace of joint responsibility and collective good" (Townsley \& Stohl, 2003, p. 604).

Furthermore, there are both extrinsic and intrinsic values to embracing corporate social responsibility. Some researchers explain, "The financial motive is an extrinsic motive of CSR. It encourages CSR because it has instrumental value for profit or income. Non-financial motives often reflect intrinsic motives that perceive CSR as an end in itself, independent from (financial) benefits. We distinguish two types of intrinsic motives: CSR as moral duty and CSR as an expression of altruism. The moral duty to be socially responsible can be derived from ethical principles of moral philosophy or from religious principles. That means that one feels obliged to do something 
because it is right, not because it is enjoyable. These moral or religious duties require an effort people might not undertake unless these acts prescribed by morality or religion" (Graafland \& Mazereeuw-Van der, 2012, p. 380-81).

Until a worldwide policy is formulated and implemented, the Crane, Matten \& Spence (2008) framework can be used to evaluate the legitimacy of an organization's current policy. The Crane et al. (2008) factors to analyze whether actions are characterized under CSR include whether (1) actions are primarily voluntary, (2) externalities are addressed, (3) multiple stakeholders are considered, (4) environmental and social interests are integrated, (5) CSR is adopted into value systems, and (6) CSR is operationalized (more than merely charitable acts). The discussion on corporate social responsibility will continue to be a critical issue for students, academicians, researchers, managers, and employees.

\section{References}

Baldoni, J. (2010). What does the organization need me to do? The Journal of Quality \& Participation, 33, 10-15.

Boulouta, I. (2013). Hidden connections: The link between board gender diversity and corporate social performance. Journal of Business Ethics, 113(2), 185-197. http://dx.doi.org/10.1007/s10551-012-1293-7

Bowen, H. R. (1953). Social responsibility ofthe businessman. New York: Harpers and Brothers.

Brammer, S., Williams, G. \& Zinkin, J. (2007). Religion and Attitudes to Corporate Social Responsibility in a Large Cross-Country Sample. Journal of Business Ethics, 71, 229-243. http://dx.doi.org/10.1007/s10551-006-9136-z

Carroll, A. B. (1979). A three-dimensional conceptual model of corporate performance. Academy of management review, 4(4), 497-505.

Cassidy, M. F. \& Medsker, K. L. (2009). Coaching and performance improvement. Performance Improvement Quarterly, 21(4), 3-4. http://dx.doi.org/10.1002/piq.20035

Cennamo, L. \& Gardner, D. (2008). Generational differences in work values, outcomes and person-organisation values fit. Journal of Managerial Psychology, 23(8), 891-906. http://dx.doi.org/10.1108/02683940810904385

Chen, P. \& Choi, Y. (2008). Generational Differences In Work Values: A Study Of Hospitality Management. International Journal of Contemporary Hospitality Management, 20(6), 595-615. http://dx.doi.org/10.1108/09596110810892182

Choudhary, N. \& Singh, N. K. (2012). Corporate Social responsibility-Competitive Advantage or Social Concern. European Journal of Business \& Management, 4(4).

Crane, A., Matten, D. \& Spence, L. J. (2008). Corporate social responsibility: Readings and cases in global context. London: Routledge, 3-20.

Debeljak, J., Krkac, K. \& Ivana, B. B. (2011). Acquiring CSR practices: From deception to authenticity. Social Responsibility Journal, 7(1), 5-22. http://dx.doi.org/10.1108/17471111111114503

Eagly, A. H. (2009). The his and hers of prosocial behavior: An examination of the social psychology of gender. American Psychologist, 64, 644-658. http://dx.doi.org/10.1037/0003-066X.64.8.644

Eagly, A. H. (2013). Sex differences in social behavior: A social-role interpretation. Psychology Press.

Edward, T. Hall. (1976). Beyond Culture. New York: Anchor Books.

Fitzpatrick, J. (2013). Business students' perceptions of corporate scoial responsibility. Age, 17(63), 86-95.

Frynas, J. G. (2012). Corporate Social Responsibility or Government Regulation? Evidence on Oil Spill Prevention. Ecology \& Society, 17(4). http://dx.doi.org/10.5751/ES-05073-170404

Garriga, E. \& Melé, D. (2004). Corporate social responsibility theories: Mapping the territory. Journal of Business Ethics, 53(1-2), 51-71. http://dx.doi.org/10.1023/B:BUSI.0000039399.90587.34

Gerlach, P. (2009). "Gender and communication: typical female vs male priorities", The Break Cycle!, 2 August. Retrieved from http://sfhelp.org/cx/gender.htm (accepted 3 August 2009).

Graafland, J. \& Mazereeuw-Van der, D. S. (2012). Motives for corporate social responsibility. De Economist, 160(4), 377-396. http://dx.doi.org/10.1007/s10645-012-9198-5

Gulbro, R. \& Herbig, P. (1996). Negotiating successfully in cross-cultural situations. Industrial Marketing Management, 25(3), 235-241. http://dx.doi.org/10.1016/0019-8501(95)00081-X

Hall, E. T. (1983). The dance of life. Garden City, NY: Anchor Press.

Hall, E. T. \& Hall, M. R. (1987). Hidden differences: Doing business with the Japanese. Garden City, NY: Anchor Press/Doubleday.

Hopkins, M. (2007). Corporate social responsibility \& international development: Is business the solution? London: Earthscan, London. 
Hostede, Geert. (1991). Cultures and organizations: Software of the mind. New York: McGraw-Hill.

Ibrahim, N. A., Howard, D. P. \& Angelidis, J. P. (2007). The Relationship between Religiousness and Corporate Social Responsibility Orientation: Are there Differences Between Business Managers and Students? Journal of Business Ethics, 78(1-2), 165-174. http://dx.doi.org/10.1007/s10551-006-9321-0

Kaifi, B. A. (2013). Organizational Behavior: Managing and Leading Organizations. Tamarac, FL: Llumina Press. ISBN: 978-1-62550-006-9.

Keegan, W. J. (1989). Global marketing management. Englewood Cliffs, NJ: Prentice-Hall.

Kim, D. \& Choi, M.-i. (2013). A Comparison of Young Publics' Evaluations of Corporate Social Responsibility Practices of Multinational Corporations in the United States and South Korea. Journal of Business Ethics, 113(1), 105-118. http://dx.doi.org/10.1007/s10551-012-1285-7

Kotler, P. \& Lee, N. (2005). Corporate social responsibility: Doing the Most Good for Your Company and Your Cause, New Jersey.

Lange, D. \& Washburn, N. T. (2012). Understanding attributions of corporate social irresponsibility. Academy of Management Review, 37(2), 300-326. http://dx.doi.org/10.5465/amr.2010.0522

Leslie, L. M., Snyder, M. \& Glomb, T. M. (2013). Who gives? Multilevel effects of gender and ethnicity on workplace charitable giving. J Appl Psychol, 98(1), 49-62. http://dx.doi.org/10.1037/a0029943

Leveson, L. \& Joiner, T. A. (2014). Exploring corporate social responsibility values of millennial job-seeking students. Education + Training, 56(1), 21-34. http://dx.doi.org/10.1108/ET-11-2012-0121

McWilliams, A. \& Siegel, D. (2001). Corporate social responsibility: A theory of the firm perspective. Academy of management review, 26(1), 117-127.

Nahavandi, A. (2006). The art and science of leadership, Ltd. Pearson Education.

Nath, L., Holder-Webb, L. \& Cohen, J. (2013). Will Women Lead the Way? Differences in Demand for Corporate Social Responsibility Information for Investment Decisions. Journal of Business Ethics, 118(1), 85-102. http://dx.doi.org/10.1007/s10551-012-1573-2

Ng, E. S. W., Schweitzer, L. \& Lyons, S. T. (2010). New generation, great expectations: a field study of the millennial generation. Journal of Business and Psychology, 25(2), 281-292. http://dx.doi.org/10.1007/s10869-010-9159-4

Nicolopoulou, K. (2011). Towards a theoretical framework for knowledge transfer in the field of CSR and sustainability. Equality, Diversity and Inclusion: An International Journal, 30(6), 524-538. http://dx.doi.org/10.1108/02610151111157738

Nonaka, I. \& Nishiguchi, T. (2001). Knowledge emergence. New York, NY: Oxford University Press.

Olivero, G., Bane, K. D. \& Kopelman, R. E. (1997). Executive coaching as a transfer of training tool: Effective on productivity in a public agency. Public Personnel Management, 26, 461-469.

Orlando, M. D. (2012). Socialization: Psychological affect on gender conflict within the American workplace. International Journal of Arts \& Sciences, 5(6), 321-328.

Parnell, J. A. \& Kedia, B. L. (1996). The impact of national culture on negotiating behaviors across borders. International Journal of Value-Based Management, 9(1), 45-61. http://dx.doi.org/10.1007/BF00420507

Sandhu, H. S. \& Kapoor, S. (2010). Corporate Social Responsibility Initiatives: An Analysis of Voluntary Corporate Disclosure. South Asian Journal of Management, 17(2), 47-80.

Simintiras, A.C. \& Thomas, A. H. (1998). Cross-cultural sales negotiations: a literature review and research propositions. International Marketing Review, 15(1), 10-28. http://dx.doi.org/10.1108/EUM0000000004481

Tian, Z., Wang, R. \& Yang, W. (2011). Consumer responses to corporate social responsibility (CSR) in china. Journal of Business Ethics, 101(2), 197-212. http://dx.doi.org/10.1007/s10551-010-0716-6

Tong, R. L. (1992). Handshakes across the sea: Cross-cultural negotiating for business success. Organizational Dynamics, 19(3), 30-40. http://dx.doi.org/10.1016/0090-2616(91)90092-N

Townsley, N. C. \& Stohl, C. (2003). Contracting corporate social responsibility. Management Communication Quarterly, 16(4), 599-605. http://dx.doi.org/10.1177/0893318902250238

Twenge, J. M., Campbell, S. M., Hoffman, B. J. \& Lance, C. E. (2010). Generational differences in work values: leisure and extrinsic values increasing, social and intrinsic values decreasing. Journal of Management, 36(5), 1117-1142. http://dx.doi.org/10.1177/0149206309352246

Wong, A., Long, F. \& Elankumaran, S. (2010). Business students' perception of corporate social responsibility: the United States, China, and India. Corporate Social Responsibility and Environmental Management, 17(5), 299-310. http://dx.doi.org/10.1002/csr.216 